\title{
Mathematics Communication of Middle School Students in Solving Geometry Problems Based on Spatial Intelligence
}

\author{
Titin Masfingatin', Swasti Maharani², Intan Sari Rufiana ${ }^{3}$, Ardhi Sanwidi ${ }^{4}$ \\ ${ }^{1}$ Department of Mathematics Education, Universitas PGRI Madiun, \\ Madiun, Indonesia \\ Email: titin.mathedu@unipma.ac.id \\ ${ }^{2}$ Department of Mathematics Education, Universitas PGRI Madiun, \\ Madiun, Indonesia \\ Email: swasti.mathedu@unipma.ac.id \\ ${ }^{3}$ Department of Mathematics Education, Universitas Muhammadiyah Ponorogo, \\ Ponorogo, Indonesia \\ Email:rufiana13@yahoo.co.id \\ ${ }^{4}$ Department of Mathematics, UNU Blitar, Blitar, Indonesia \\ Email: ardhisanwidi@unublitar.ac.id
}

\begin{abstract}
Students' abilities in mathematical communication are related to their ability in problem solving. When students are able to communicate mathematically well, students understand concepts that are communicated both verbally and in writing. These abilities support students so that they are able to solve problems. The purpose of this study is to describe students 'mathematical communication in solving geometry problems based on students' spatial intelligence. This type of research is descriptive qualitative. This research was conducted at Takeran 1 Junior High School in the 2018/2019 school year. The research subjects consisted of two students, namely 1 student with high spatial intelligence and 1 student with moderate spatial intelligence. Data collection techniques using tests and interviews. Analysis of the data used is data reduction, data presentation and drawing conclusions. The results of the study are students with high spatial intelligence and are communicating mathematically by expressing mathematical ideas in the form of notations and mathematical symbols based on problems, and writing mathematical symbols in the form of formulas that will be used to solve problems. Students with high spatial intelligence interpret and evaluate mathematical ideas visually / graphically, state and use comprehensive representations to write and explain concepts and solutions to problem solving, and state conclusions from the results of problem solving more fully than students with moderate spatial intelligence. In addition, students with high spatial intelligence can evaluate ideas more thoroughly so that they are able to apply many or more problem solving strategies. Mathematical communication (both written and oral) students with high spatial intelligence tend to be better than students with moderate spatial intelligence.
\end{abstract}

Keywords: Mathematical communication; problem-solving; spatial intelligence

\section{Introduction}

Mathematics as one of the languages used in communication using patterns, symbols or symbols. M atematika have a role in developing the communication skills of students. Mathematical communication has been used in everyday life as well as in learning mathematics. therefore, mathematical communication 
becomes one of the basic mathematical abilities that students must master well [1]. Mathematical communication is very important in mathematics learning [2], [3]. Student ability to communicate ideas through symbols, tables, diagrams or other media in order to clarify the situation or problem as an objective in learning mathematics [4]. The ability of students to communicate ideas and concepts of mathematics understanding of students to mathematical concepts.

In addition to mathematical communication, students' ability in problem solving is an important ability to be trained. The main purpose of learning mathematics is that students have the ability to solve problems which include the ability to understand problems, design mathematical models, solve models and interpret the solutions obtained [1], [4]. This suggests that learning activities should be focused so that students have the ability to solve problems.

Problem solving is finding the right way to achieve goals [5]. Polya [6] argues that the important stages in solving problems are understanding problems, planning problem solving, carrying out problem solving plans and checking the completeness of problem solving. Especially in solving mathematical problems, students must have good abilities to be able to undergo each step of problem solving well.

The importance of problem solving skills requires educators to hold a learning process that involves problem solving activities. It is intended that students are trained in problem solving. But not all students welcome this kind of learning. Most students complained of difficulty in solving problems in the form of problems. Especially when students study geometry. As a result students' mathematics learning achievement becomes less optimal.

Geometry and measurement are material that is studied in a first or equivalent school. Geometry material requires students to have good visualization skills. Most students memorize the concept of geometry. This will become an obstacle when students memorize too many concepts so that they will eventually forget. Under these conditions students need good skills in understanding mathematical concepts.

Problem solving ability is a high level thought process. To be able to solve problems students must be able to analyze mathematical concepts and be able to understand other concepts so they can find solutions to problems. As students are able to solve problems, they must understand the concepts well. Mathematical communication can help the process of perfecting the understanding of mathematical ideas, and help build meaning and permanence of an idea of the process of perfecting the understanding of mathematical ideas, and help build meaning and permanence of an idea [7], [8]. Students who have good mathematical communication skills show that an understanding of mathematics is also good which can affect the ability to solve problems. Thus mathematical communication skills support students' ability in problem solving [9], [10]. Mathematical communication skills can be used to build an understanding of students are permanently on mathematical concepts making it easier for her to make connections between concepts to arrive at solving math problems.

Mathematical communication can be recognized from various aspects. According to [11] a mathematical communication spec includes : (1) expressing mathematical ideas through oral, written as well as visually describing, (2) interpreting and evaluating mathematical ideas both verbally and in writing, (3) using mathematical terms, symbols, and structures to model mathematical situations or problems an indicator of mathematical communication ability delivered by [12]. Mathematical Communication Skills (MCS) refer to the students' ability to (1) arrange and link their mathematical thinking through communication; (2) communicating their logical and clear mathematical thinking to their friends, teachers, and others; (3) analyze and assess mathematical thinking and strategies used by others; and (4) use mathematical language to express mathematical ideas correctly [12]. The indicators of mathematical communication skills used in this study are: (1) expressing mathematical ideas in the problem, (2) interpreting and evaluating mathematical ideas visually / pictures, (3) stating and using a comprehensive representation to solving problems, and (4) stating conclusions from the results of problem solving. Mathematical communication of students in problem solving can be identified based on mathematical communication indicators in understanding problems, compiling a plan of solving, implementing a plan of solving and re-examining the results of solving.

Solving geometry problems is also influenced by the level of intelligence students have, one of which is spatial intelligence. Spatial intelligence is the ability to visualize something in the mind in two or three dimensions. According to Lwin et al., (2008) one of the important roles of having spatial visual intelligence is to be able to develop high-level thinking and problem solving skills. The higher the spatial intelligence 
possessed, the easier it is for students to develop highlevel thinking and problem solving skills.

Several studies have been conducted relating to mathematical communication in solving geometry problems [14], [15]. Research [16] states that there is a positive correlation between spatial intelligence and mathematical communication of students. However, it has not been able to provide a clear description of how the relationship between spatial intelligence and mathematical communication skills of students in problem solving. Therefore, this study wants to describe how mathematical communication of students with high and low spatial intelligence in the process of solving geometry problems

\section{Research Method}

This study was sealed there right in SMP Negeri 1 school year Takeran 2018 /201 9. The research subjects consisted of 2 students, namely 1 student with high spatial intelligence and 1 student with low spatial intelligence. This research is a descriptive qualitative research that describes the profile of students' mathematical communication skills in depth and naturally when solving geometry problems.

Data collection techniques in this study used test and interview techniques. Instruments major in this study is the researchers themselves, while supporting the instrument is an instrument test spatial, geometrical problems and guide the interview. Before the instrument is used, it is first validated by a validator, namely 2 SMP / MTs teachers. Testing validity the data in the study is using the technique of triangulation techniques to determine the validity of the data. Analysis of data: (1) Data Reduction (Data Reduction), (2) Data Display (Data Presentation), (3) Conclusion Drawing / Verification (Withdrawal Conclusion).

\section{Result and Discussion}

The study begins with the provision of spatial intelligence tests with geometry problem solving tests. The test is given to class V IIA as many as 35 students. The results of spatial tests and problem solving tests are then analyzed. Determination of research subjects is based on the results of spatial intelligence tests that have been tested for validity. After students have determined their spatial intelligence, then one student is taken with high spatial intelligence and one moderate. Both subjects must have the ability to express answers to the results of problem solving verbally and in writing. Problem solving tests were analyzed relating to mathematical communication skills based on mathematical

$$
\begin{aligned}
& \text { P. } 2.2 .1 .19 \quad: \quad \text { Try now consider the second question! } \\
& \text { What information do you get from the } \\
& \text { problem? } \\
& \text { S. 2.2.1.19 : It is known that LP is equal to } 864 \mathrm{~cm}^{2} \text {, } \\
& \text { Diket, luas pernukaon. } .869 \mathrm{~cm}^{2} \\
& \text { Dit : P \& V? } \\
& \text { P. 2.2.1.21 : What steps did you use to solve the } \\
& \text { problem? } \\
& \text { S. } 2.2 .121 \text { : First find the length of the side with the } \\
& \text { Then after that? } \\
& \text { P. } 2.2 .122 \text { : Then after that? } \\
& \text { S. }{ }_{2.2 .122} \quad \text { : volume using the volume formula is } \\
& \text { equal to s cube. } \\
& V=\bar{S}_{3}^{3}
\end{aligned}
$$

communication indicators. The selected subjects were then interviewed with regard to the geometry problem solving test. The written results and subject interviews relating to mathematical communication indicators are described as follows.

\subsection{Subject 1 (Subject with high spatial intelligence)}

\subsubsection{Express the mathematical ideas that are in the problem.}

The results of completion of subject 1 , namely subjects with high spatial intelligence. The following are the results of the written test and interview subject 1 :

\section{Interview 1}

$$
\begin{aligned}
& \text { P. 2.1.1.4 : Look at the first question! (showing the } \\
& \text { Diket: } V: 315 \mathrm{~cm}^{3} \\
& P=9 \mathrm{~cm} \\
& \text { P. 2.1.1.5 : What was asked? } \\
& \text { S. 2.1.1.5 : Beam surface area } \\
& \text { Dit: L } p_{8} \text { ? }
\end{aligned}
$$




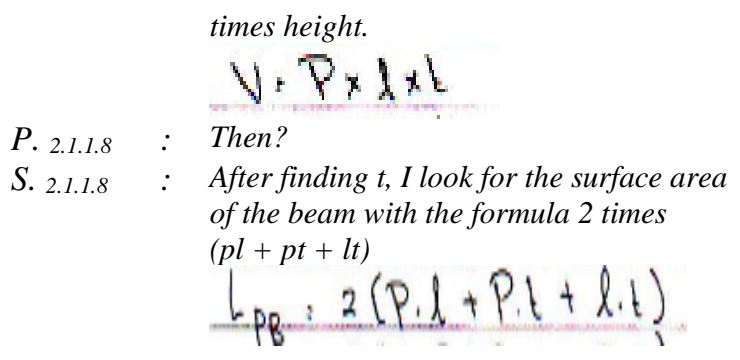

Mathematical ideas in the form of mathematical language (symbols, symbols, notations and mathematical equations) that exist in the problem of beams. Subject 1 express mathematical ideas in a problem that is by stating information known to use symbol-mathematical symbols. The subject explains that the information known is $V=315 \mathrm{~cm}^{3}, p=$ $9 \mathrm{~cm}$ and $l=7 \mathrm{~cm}(\boldsymbol{S} .2 .1 .1 .4)$ and the surface area of the beam ( $S$. 2.1.1.5) is asked, and it states a mathematical equation in the form of a formula that will used namely $V=p \times l \times t\left(S_{\text {.2.1.1. } .7)}\right)$ and $L p b=2(p . l+$ p.t + l.t $)($ S.2.1.1.8).

\section{Interview 2}

Subject with high spatial intelligence in stating mathematical ideas in the form of information known problems that the $L P=864 \mathrm{~cm}^{2}$ and asked $\mathrm{P}$ and $\mathrm{V}$ $\left(S_{\text {2.2.1.19 }}\right)$, as well as mathematical equations expressed in the form of formulas to be used that formula $L p=$ $6 s^{2}$ to determine the side length $\left(S_{\cdot 2.2 .1 .21}\right)$, and the volume of the cube using the formula $V=s^{3}\left(S_{\text {2.2.1.22 }}\right)$.

\subsubsection{Interpret and evaluate mathematical ideas visually / pictures.}

Interpreting and evaluating mathematical ideas visually / image that is visualizing the problem in the form of block images and explaining any information that is in the problem. The following are written test results and subject 2 interviews related to the second indicator:

\begin{tabular}{|c|c|c|}
\hline \multicolumn{3}{|c|}{ Interview 1} \\
\hline P. 2.1 .2 .6 & $\therefore$ & $\begin{array}{l}\text { Try to explain the information that you } \\
\text { have obtained! } v, p, l \text { what is that? }\end{array}$ \\
\hline S. ${ }_{2.1 .2 .6}$ & $:$ & $V$ volume,$p$ length and $l$ width. \\
\hline$P .{ }_{2.1 .2 .38}$ & $\therefore$ & $\begin{array}{l}\text { Try to explain the information you write } \\
\text { in the picture! }\end{array}$ \\
\hline$S_{2.1 .2 .38}$ & $\therefore$ & (Pause) \\
\hline$P .{ }_{2.1 .2 .39}$ & $\cdot$ & What are symbols $A, B$, etc.? \\
\hline S. ${ }_{2.1 .2 .39}$ & & $\begin{array}{l}\text { I wrote the symbols } A, B \text {... etc to } \\
\text { make it easier to find out the base of } \\
\text { building the beam space. } \\
\text { So I gave ABCD information } \\
\text { rectangular. }\end{array}$ \\
\hline
\end{tabular}

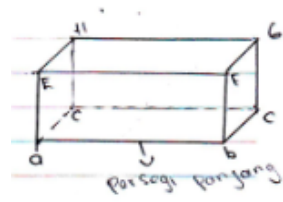

Subject with high spatial intelligence to interpret and evaluate mathematical ideas in a visual / image to explain the symbol written by problems, that $\mathrm{p}$ is the length, 1 is the width, $\mathrm{V}$ is the volume $\left(S_{\cdot 2.1 .2 .2 .6}\right)$. The subject visualized the problem in the form of a block drawing with complete information and elements and stated that the symbols A, B, C ... etc. in the picture were used to determine the rectangular base of the beam $\left(S_{\cdot 2.1 .2 .39}\right)$.

\section{Interview 2}

$P ._{2.22 .20} \quad$ : Try to give a description of the information you have obtained! $V, p$, what is LP?

$S_{2.22 .20} \quad: \quad V$ is volume, $p$ is side length and $L P$ is surface area.

$P ._{2.22 .45} \quad: \quad$ Try to look at the picture of the cube. What do you mean by writing square?

$S_{2.22 .46}$ : It means that the square is the base of the cube bu.

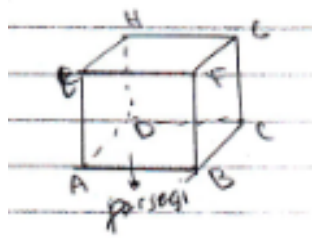

Subject 1 interpret and evaluate mathematical ideas in a visual/image to explain $\mathrm{p}$ is the length, LP is the surface area, $\mathrm{V}$ is the volume $\left(S_{\cdot 2.2 .2 .20}\right)$. The subject visualized the problem in the form of a cube image accompanied by complete information and elements and the subject implied that the symbols A, B, C ... etc. in the picture were used to know that the base of the cube was square $\left(S_{\cdot 2.2 .2 .46}\right)$

\subsubsection{Indicator 3: States and uses a comprehensive representation to solve the problem.}

Using a comprehensive representation that is using concepts or formulas that are appropriate for solving problems.

\section{Interview 1}

P. 2.1.3.9 : Explain how are your stages in solving these problems?

S. 2.1.3.9 : Find height with volume formula, volume equal to length times width times height, 315 equals 9 times 7 times $t, 315$ equals 63 times $t, 315$ divided by 63 equals $t, t$ equals 5. Then lpb equals 2 times length times 
width plus length times height plus width times height, equals 2 times 9 times 7 plus 9 times 5 plus 7 times 5,equals 2 times 63 plus 45 plus 35 ,

equals 2 times 143, equals $286 \mathrm{~cm}$.

\begin{aligned}$V & =P \times l \times t \\ 315 & =9 \times 7 \times t \\ 315: & 63 \times 1 \\ 315 & : 1 \\$\hline 63 & \\ 5 & $: t \\ L_{P B} & =2(P \cdot l+P \cdot t+l \cdot t) \\ : & 2(9 \cdot 7+y \cdot 5+7 \cdot 5) \\ : & 2(63+45+35) \\ & 2(193) \\ : & 286 \mathrm{~cm}\end{aligned}$

P. 2.1.3.10 : Are there other alternative solutions?

S. 2.1.3.10: There ma'am.

P. 2.1.3.11 : How?

S. 2.1.3.11 : I made the formula for the beam volume $V=$ area of base $x$ height. Because the base of the rectangular block is the area of the base length times width equal to 63. So to find height,

volume equals area of base height, 315 divided by 63, height equals 5 .

For surface area equal to 286 (while writing)

$V=$ louas alas $x t$

W: $P \times \ell$

$=9 \times 7$

63

$\checkmark=L \cdot \nabla \times t$

$315=63 \times t$

$t=\frac{315}{63}=5$

$L P_{3}=286$

P. 2.1.3.12 : Are there other alternatives?

S. 2.1.3.12: No.

P. 2.1.3.15 : Are you sure about your answer?

S. 2.1.3.15: I have.

The male subject in expressing and using a comprehensive representation to solve the problem is to apply two solving strategies to express mathematical concepts, namely using a formula to find $t$, so that the result of $t=5 \mathrm{~cm}$ and the surface area formula are $286 \mathrm{~cm}^{2}$ ( $\left.S_{\cdot 2.1 .3 .9}\right)$. Subject use alternate alternate resolution that is currently seeking high, the subject using a different volume formulas First the subject determines the area of the base that is rectangular in shape that is 9 times 7 is obtained 63 . Then the obtained $\mathrm{t}$ of volume divided by $\left(S_{\cdot 2.1 .3 .11}\right)$. The subject is sure of the answer $\left(S_{\cdot 2.1 .3 .15}\right)$. Thus, the subject applies more than one strategy to write down and explain the concepts and solutions to work on the beam problem.

\section{Interview 2}

P. 2.2.3.23 : Explain the steps you took in working on the problem!

$S_{2.23 .23} \quad: \quad$ First, LP is equal to $6 s$ squared, 864 is equal to $6 s$ squared, 864 divided by 6 is $s$ squared, the root of 144 is equal to s squared, 12 is equal to side. Then the volume is the same as the cube side, equal to 12 cube is equal to $1728 \mathrm{~cm}$.

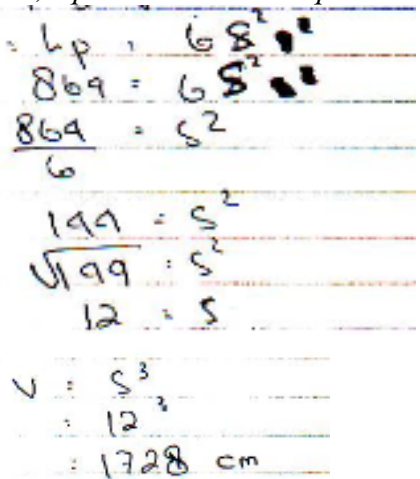

$P_{.2 .23 .25} \quad: \quad$ Are there other alternatives?

S. 2.2 .325 : There ma'am.

P. ${ }_{2.23 .26}:$ How? Try to explain!

S. ${ }_{2.23 .26}$ : Like that. I am looking for surface area by means of $L P=6 x$ base area. Because the base of the cube is square so it uses the formula sx s.

$P$ 2.2.3.27 $\quad$ : Oo so the difference is only at the beginning, huh? To calculate the next way the same as the previous way?

$S_{\text {2.2.3.27 }}$ : Yes ma'am. (while writing answers)

$L_{p}=6$. Luas alas tabus.

Q. $a: 6 \cdot(5 \times 5)$

$86 a: 6 s^{2}$

$86 a=s^{2}$

$0199: 5^{2}$

$\frac{0199: s^{2}}{199}=2^{2}$

$12=5 x$

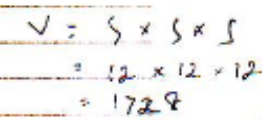

$P$ 2.2.2.29 $\quad$ : Are there still alternatives?

S. 2.23.29 : No.

P. 2.2.3.30 : Are you sure about your answer?

S. ${ }_{223.30}$ : Already ma'am.

Subject declare and use a thorough representation to solve the problems with implementing many strategies (more than one strategy) is a two-solving strategies to express mathematical concept, which uses a formula L. $P$ cube $=6 s^{2}$, to find $\mathrm{s}$, in order to obtain the result $\mathrm{s}=12 \mathrm{~cm}$ and volume formulas $V k u b u s=s^{3}$ obtained $1728 \mathrm{~cm}^{3} \quad\left(S_{\cdot 2.2 .3 .23}\right)$ and use another alternative settlement to find the length of the sides using the formula L.P cube $=6 \times$ Luas Alas . Resulting in the same 
answer, which is the side length of $12 \mathrm{~cm}$ and the volume of the cube $1728 \mathrm{~cm}^{3}\left(S_{\cdot 2.2 .3 .26}, S_{\cdot 2.2 .3 .27}\right)$. The subject is sure of the answer $\left(P_{\cdot 2.2 .3 .30}\right)$.

\subsubsection{Indicator 4: States the conclusions from the results of problem solving.}

To state a conclusion is to state the end result in accordance with the problem in question. The following are written test results and subject 2 interviews related to the fourth indicator:

\section{Interview 1}

$P$. 2.1.4.13 : So what can you conclude from the results of your settlement?

$S_{2.1 .1 .13} \quad$ : The surface area of the pencil box in the shape of a block is $286 \mathrm{~cm}^{2}$

Jodi luas parmukano kotok pansil yong barbenty boled
adalah $786 \mathrm{~cm}$

Subject 1 in stating conclusions from the settlement of the problem by stating a conclusion in accordance with the calculation results of the settlement is the surface area of a pencil box shaped beam is 286 $\mathrm{cm}^{2}\left(. S_{\cdot 2.1 .4 .13}\right)$

\section{Interview 2}

$P{ }_{2.2424} \quad$ : So, what is the final result that you can conclude?

$S_{2.2 .424}$ : The side length of the toy cube is 12 and the volume is 1728

$$
\text { jad ponfong } 81512 \text { don volume kotot maknon } 1728 \mathrm{~cm}
$$

The male subject stated the conclusion of the results of solving the problem by writing the side length of the cube-shaped toy was $12 \mathrm{~cm}$ and the volume of the cubeshaped toy was $\left(S_{\cdot 2.2 .4 .32}\right)$

\subsection{Subject 2 (Subject with moderate spatial intelligence)}

\subsubsection{Indicator 1 : Express mathematical ideas that} are in the problem
$P_{3.1 .1 .4} \quad$ : Look at the first question! What is known from the problem?
S. ${ }_{3.1 .14}$ : Volume equals $315 \mathrm{~cm}^{3}, P$ equals $9 \mathrm{~cm}$, width equals $7 \mathrm{~cm}$

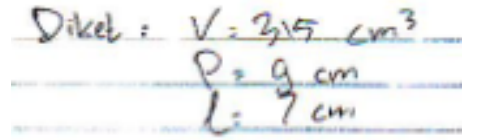

$P .3 .1 .15 \quad$ : What is asked of this problem?

S. ${ }_{3.1 .1 .5}$ : Surface area of a pencil case.

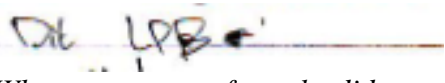

$P_{3.1 .1 .9}$ : What strategy or formula did you use to solve?

$S_{3.1 .19} \quad$ : Use volume to find $t$ first, that is, $p$ times $l$ times $t$

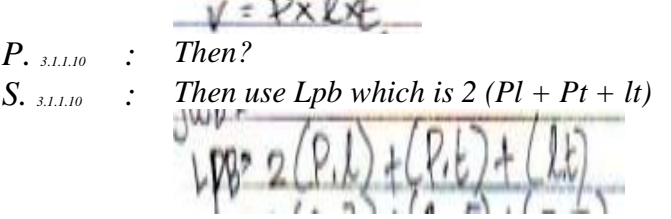

\section{Interview 2}

Subject 2 express mathematical ideas that exist in the form of information known problems in the form of symbols and mathematical notation is $V=315 \mathrm{~cm}^{3}$ $p=9 \mathrm{~cm}$ and $l=7 \mathrm{~cm}\left(S_{\cdot 3.1 .1 .4}\right)$ and asked the beam surface area $\left(S_{\cdot 3.1 .1 .5}\right)$. The subject stated mathematical equations in the form of formulas to be used namely $=p \times l \times t\left(S_{\cdot 3.1 .1 .9}\right)$ and $L p b=2(p . l+p . t+l . t)$ $(S \cdot 3.1 .1 .10)$

\section{Interview 2} $P .3 .2 .1 .19:$ Try now consider the second question!
What information do you get from the problem?

$S_{.32 .1 .19}$ : The surface area of the cube is $864 \mathrm{~cm}^{2}$ and side length and volume of the cube are asked.

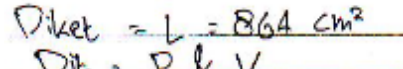

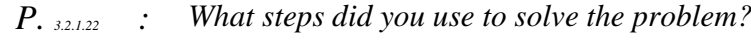

S. ${ }_{3.2 .122} \quad$ : First find the length of the sides with the formula for the surface area of the cube equal to s squared $L P: 6 s_{-2}^{2}$

$P_{.32 .123} \quad: \quad$ Then after the surface area is looking for?

$S_{\text {3.2.1.23 }}$ : Look for a volume using the formula s cube.

$$
V=5^{3}
$$

Subject 2 express mathematical ideas on issues such as the form of symbols and mathematical notation related to the information known is $L=864 \mathrm{~cm}^{2}$ and asked $\mathrm{P}$ and $\mathrm{V}\left(\mathrm{S}_{3.2 .1 .19}\right)$, as well as mathematical equations expressed in the form of formulas to be used is the formula $L P=6 s^{2}$ to determine the side length $\left(S_{3.2 .1 .22}\right)$, and the volume of the cube using formula $V=s^{3}\left(\mathrm{~S}_{\cdot 3.2 .1 .23}\right)$.

\subsubsection{Indicator 2: Interpret and evaluate mathematical ideas visually / images.}

\section{Interview 1}

P. 3.1.2.4 : What is the pencil case shaped? 
S. 3.1.2.4: Beam.

P. 3.1.2.7 : Look at your drawings!

Do you think it's appropriate?

S. 3.1.2.7 : Hmm .. already mom. (see the picture)

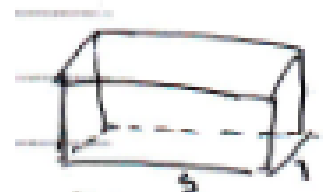

P. 3.1.2.8 Try to explain the information that you have obtained! $V, P, l$ what is that?

S. 3.1.2.8 $\quad V$ is volume, $P$ is length and $l$ is width, $b u$.

Subject 2 interpret and evaluate mathematical ideas in a visual / image to explain $p$ is the length, $l$ is the width, $V$ is the volume $\left(S_{\cdot 3.1 .2 .8}\right)$. Subjects visualize problems in the form of block images with complete elements but are not accompanied by information in the form of mathematical symbols $\left(S_{\cdot 3.1 .2 .7}\right)$.

\section{Interview 2}

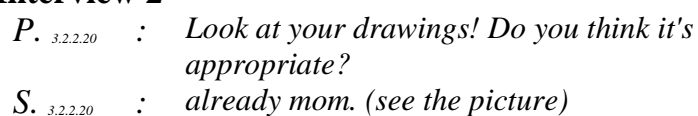

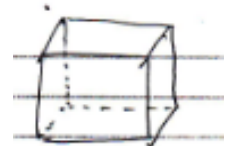

$P_{.32 .221}:$ Try to give a description of the information you

have obtained! $V, P$, what is LP?

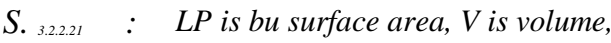

$P$ is side length.

Subject 2 interpret and evaluate mathematical ideas in a visual / image to explain $\mathrm{p}$ is the length of the sides, LP is the surface area, $V$ is the volume $\left(S_{\cdot 3.2 .2 .21}\right)$. The subject visualized the problem in the form of a cube image accompanied by complete elements but not accompanied by an explanation $\left(S_{\text {.3.2.2.22 }}\right)$.

\subsubsection{Indicator 3: States and uses a comprehensive representation to solve the problem.}

\section{Interview 1}

P. ${ }_{3.1 .3 .11} \quad$ : Explain how are your stages in solving these problems?

$S_{3.1 .3 .11} \quad$ : Find height with volume formula, volume equal to length times width times height, 315 equals 9 times 7 times $t, 315$ equals 63 times $t, 315$ divided by 63 equals $t$, $t$ equals 5 . Then lpb equals

2 times length times width plus length times height

plus width times height, equals 2 times 9 times 7 plus 9 times 5 plus 7 times 5 , equals 2 times 63 plus 45 plus 35, equals 2 times 143, equals 286 $\mathrm{cm}$.

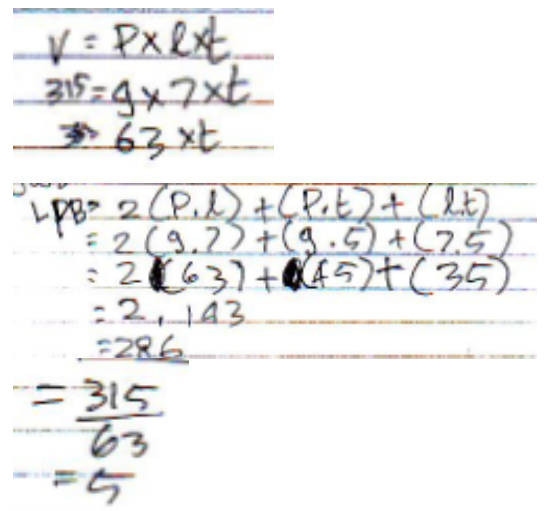

$\begin{array}{ll}P .{ }_{3.1 .3 .12} & : \quad \text { Are there other alternative solutions? } \\ S_{3.1 .3 .12} & : \quad \text { No ma'am. } \\ P .{ }_{2.1 .1 .15} & : \quad \text { Are you sure about your answer? } \\ S .{ }_{2.1 .3 .15} & : \quad \text { I have. }\end{array}$

Subject two states and uses a thorough representation to solve the problems with implementing the completion strategy to express mathematical concept, which uses the formula $V=p \times l \times t$ to find $\mathrm{t}$, so the result $t=5 \mathrm{~cm}$ and the formula for the surface area $L=2(p \times l)+2(l \times t)+2(p \times t)$ was obtained $286 \mathrm{~cm}^{2}(\mathrm{~S}$. 3.1.3.11). The subject is sure of the answer (S. 3.1.3.14)

Interview 2

P. ${ }_{3.2 .3 .24}$ : Explain the steps you took in working on the problem!

$S_{3.2 .324}$ : First, the surface area is equal to $6 \mathrm{~s}$ squared, 864 is equal to $6 s$ squared, 864 divided by 6 is equal to $s$ squared, the root of 144 is equal to $s$ squared, 12 is equal to the side. Then the volume is the same as the cube side, equal to 12 cube is equal to $1728 \mathrm{~cm}$.
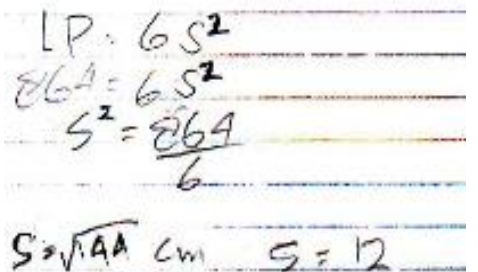
$V=5^{3}$

\section{$=12^{3}$}

\section{$=1728$}

$P_{3.3 .3 .26}:$ Are there other alternatives?

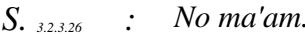

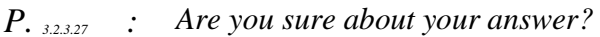

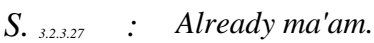

The female subject states and uses a comprehensive representation to solve the problem by applying a solution to the mathematical concept, that is, using a formula L. P kubus $=6 s^{2}$ to find $\mathrm{s}$, so that the result $\mathrm{s}$ $=12 \mathrm{~cm}$ and the volume formula is 
obtained $(S$. 3.2.3.24 $)$. The subject is sure of the answer (P. 3.2.3.27).

\subsubsection{Indicator 4: States the conclusions from the results of problem solving.}

\section{Interview 1}
$P ._{3.1 .413}$ : So what can you conclude from the results of your settlement?

$S_{3.1 .413}:$ The surface area of the beam is $286 \mathrm{~cm}$

$$
\text { jadi LPB adalah } 286
$$

Subject stated conclusions from the settlement of the problem by stating that conclusion, but less precise beam surface area is $286 \mathrm{~cm}(S$. 3.1.4.13) . the subject did not write down the volume units correctly.
Interview 2

$P ._{3.2425} \quad: \quad$ So, what is the final result that you can conclude?

$S_{3.2 .25}$ : So the side length is $12 \mathrm{~cm}$ and the volume of the cube is $1728 \mathrm{~cm}$.

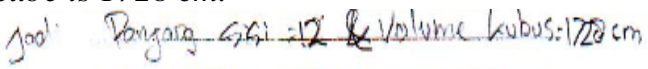

Subject 2 stated conclusions from the settlement of the problem by stating a conclusion, but less precise, namely the side length is $12 \mathrm{~cm}$ and the volume of a cube is $(S$. 3.2.4.25).

The mathematical communication of each student is presented in Table 1 .

Table 1. Mathematical Communication of Students in Solving Geometry Problems

\begin{tabular}{|c|c|c|c|}
\hline \multirow[t]{2}{*}{ No } & \multirow{2}{*}{$\begin{array}{l}\text { Mathematical } \\
\text { Communication } \\
\text { Indicator }\end{array}$} & \multicolumn{2}{|c|}{ Student Spatial Intelligence } \\
\hline & & High & 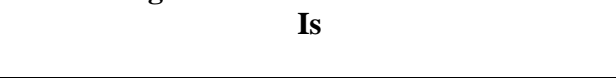 \\
\hline 1 & $\begin{array}{l}\text { Express } \\
\text { mathematical ideas } \\
\text { that exist in the } \\
\text { problem }\end{array}$ & $\begin{array}{l}\text { Students express mathematical ideas in } \\
\text { the form of symbols, symbols and } \\
\text { mathematical notations related to } \\
\text { information that is known and asked in } \\
\text { the problem. Student write } \\
\text { mathematical symbols in the form of } \\
\text { formulas to be used in solving the } \\
\text { problems }\end{array}$ & $\begin{array}{l}\text { Students express mathematical ideas in the } \\
\text { form of mathematical symbols and } \\
\text { notations related to information that is known } \\
\text { and asked in the problem. In } \\
\text { addition students write mathematical equations } \\
\text { in the form of formulas that will be used in } \\
\text { solving problems. }\end{array}$ \\
\hline 2 & $\begin{array}{l}\text { Interpret and } \\
\text { evaluate } \\
\text { mathematical ideas } \\
\text { visually / images }\end{array}$ & $\begin{array}{l}\text { Students interpret and evaluate } \\
\text { mathematical ideas visually / images by } \\
\text { making visualizations of problems in the } \\
\text { form of images accompanied by } \\
\text { complete information and elements. }\end{array}$ & $\begin{array}{l}\text { Students interpret and evaluate mathematical } \\
\text { ideas visually / images by making a visualization } \\
\text { of problems in the form of images but the } \\
\text { information in the picture is incomplete. }\end{array}$ \\
\hline 3 & $\begin{array}{l}\text { States and uses a } \\
\text { comprehensive } \\
\text { representation to } \\
\text { solve the problem. }\end{array}$ & $\begin{array}{l}\text { Students state and use comprehensive } \\
\text { representations by applying more than } \\
\text { one completion strategy to express } \\
\text { mathematical concepts }\end{array}$ & $\begin{array}{l}\text { Students state and use comprehensive } \\
\text { representations by applying a solution to express } \\
\text { mathematical concepts. }\end{array}$ \\
\hline 4 & $\begin{array}{l}\text { States the } \\
\text { conclusions from } \\
\text { the results of } \\
\text { solving the problem }\end{array}$ & $\begin{array}{l}\text { Students state the conclusions of the } \\
\text { results of problem solving by stating } \\
\text { conclusions in accordance with the } \\
\text { results of calculations obtained from the } \\
\text { solution and in accordance with the } \\
\text { context of the problem. }\end{array}$ & $\begin{array}{l}\text { Students state the conclusions from the results of } \\
\text { solving the problem in accordance with the } \\
\text { results of the calculation obtained from the } \\
\text { solution but not in accordance with the context } \\
\text { of the problem. The subject wrote inaccurate and } \\
\text { incomplete conclusions. }\end{array}$ \\
\hline Othe & findings & $\begin{array}{l}\text { Students with high spatial } \\
\text { intelligence apply problem solving in } \\
\text { other different ways, besides the } \\
\text { commonly used } \\
\text { formulas. Students show another way } \\
\text { that is by connecting the base area and } \\
\text { height of the building blocks and cubes. }\end{array}$ & $\begin{array}{l}\text { Students with spatial intelligence are better at } \\
\text { writing communication than verbal } \\
\text { communication. Students look nervous when } \\
\text { interviewed regarding problem solving. }\end{array}$ \\
\hline
\end{tabular}


Based on the results of data analysis in Table 1. It can be seen that between students with high and moderate spatial intelligence there are differences. S ISWA with high spatial intelligence level, have good communication skills in problem solving mathematical geometry. Students can solve problems better than students who have a moderate level of spatial intelligence. This is supported by the results of research by Murtafi'ah \& Masfingatin (2015). The results of the study indicate that students' thinking processes have a high level of spatial intelligence in solving geometry problems, in understanding the problem of doing assimilation thinking processes. In making problem solving plans, the process of thinking assimilation is less than perfect and accommodation. In implementing the problem solving plan, the process of thinking assimilation. In reexamining the results of solving the problem of the process of thinking accommodation but not perfect. This is also supported by Hass [18] one of the characteristics of students is problem solving, students with high spatial visual intelligence have divergent / diffuse thoughts, preferring unconventional solutions and various strategies to solve problems.

In addition to solving geometry problems, students with high levels of spatial intelligence have the ability to describe problems in a better visual form than students who have moderate and low levels of spatial intelligence. Based on other findings in this study that students with high spatial intelligence solve the problem of beam volume by multiplying the base area and beam height. This shows one of the characteristics of students, namely the imagination (imaging). According Hass [18] students with high visual-spatial intelligence more to see than to listen. Students find it easier to understand perspective problems such as shifting, translating, rotating, and learning concepts based on what is seen.

Students with high spatial intelligence have good spatial abilities, so they are able to see a problem as a whole. Students with a high level of spatial intelligence have better creativity, thinking and skills in problem solving. This is supported by [13] that spatial visual intelligence is important for every student to have, because by developing spatial intelligence students will increase creativity, improve memory, develop high-level thinking and problem solving skills. Students with good mathematical communication skills will also have good problem solving abilities [9]. Thus it is important to improve students' spatial ability in learning.

\section{Conclusion}

The conclusion of this study is the mathematical communication skills of junior high school students who have a high level of spatial intelligence and are writing and verbally expressing mathematical ideas that exist in problems in the form of symbols, symbols and mathematical notations. However, indicators interpret and evaluate mathematical ideas visually / draw, state conclusions from the results of problem solving and state and use comprehensive representations to write and explain concepts and solutions to solve problems of students with spatial intelligence tend to be better than students with moderate spatial intelligence. Another result is revealed also that students with high spatial intelligence can evaluate ideas more thoroughly so that they are able to apply more than one problem solving strategy. Mathematical communication (both written and verbal) students with high spatial intelligence tend to $1 \mathrm{e}$ bih well compared with students with moderate spatial intelligence. Thus it is suggested that the geometry math learning materials using the tool aids or media that can improve the spatial abilities of students.

\section{References}

[1] NCTM, Principles and Standards for School Mathematics. VA: NCTM, 2000.

[2] R. Johar, E. Junita, and S. Saminan, 'Students' Mathematical Communication Ability and Self-Efficacy Using Team Quiz Learning Model', Int. J. Emerg. Math. Educ., vol. 2, no. 2, p. 203, 2018.

[3] C. J. Young, S. C. Levine, and K. S. Mix, 'The connection between spatial and mathematical ability across development', Front. Psychol., vol. 9, no. JUN, pp. 1-7, 2018.

[4] Permendiknas, 'Standart Isi Untuk Satuan Pendidikan Dasar dan Menengah', no. May, p. 58, 2006.

[5] J. W. Santrock, Psicología del desarrollo en la adolescencia. 2003.

[6] E. S. Winarni and S. Harmini, Matematika untuk PGSD. Bandung: Remaja Rosdakarya, 2011.

[7] K. Hirschfeld-Cotton, 'Mathematical Communication, Conceptual Understanding, and Students' Attitudes Toward Mathematics', Action Res. Proj., vol. 4, p. 54, 2008.

[8] C. Indah Nartani, R. Aliim Hidayat, and Y. Sumiyati, 'Communication in Mathematics Contextual', Int. J. Innov. Res. Educ. Sci., vol. 4, no. 4, pp. 2349-5219, 2015.

[9] P. Paridjo and S. B. Waluya, 'Analysis Mathematical Communication Skills Students In The Matter Algebra Based Nctm', IOSR J. Math., vol. 13, no. 01, pp. 60-66, 2017.

[10] A. Qohar, 'Pengembangan Instrumen Komunikasi Matematis Untuk Siswa SMP', Pros. Semin. Nas. 
Pendidik. Mat. FMIPA, no. 5, pp. 44-57, 2011.

[11] N. Agustyaningrum, 'Implementasi Model Pembelajaran Learning Cycle 5e Untuk Meningkatkan Kemampuan Komunikasi Matematis Siswa Kelas Ix B Smp Negeri 2 Sleman', Semin. Nas. Mat. dan Pendidik. Mat. (Vol. 377), 2011.

[12] D. B. Widjajanti, 'Mengembangkan Kecakapan Matematis Mahasiswa Calon Guru Matematika Melalui Strategi Perkuliahan Kolaboratif Berbasis Masalah', Pros. Semin. Nas. Penelitian, Pendidik. dan Penerapan MIPA, Fak. MIPA, Univ. Negeri Yogyakarta, vol. 14, p. 169, 2011.

[13] M. Lwin, A. Khoo, K. Lyen, and C. Sim, Cara mengembangkan berbagai komponen kecerdasan. Jakarta: Indeks, 2008.

[14] N. N. Hikmawati, N. A. Nurcahyono, and P. S. Balkist, 'Kemampuan Komunikasi Matematis Siswa Dalam Menyelesaikan Soal Geometri Kubus Dan Balok', Prisma, vol. 8, no. 1, p. 68, 2019.

[15] D. C. Murti and H. Fitriyani, 'Profil Kemampuan Komunikasi Matematika Siswa Kelas Viii Smp Muhammadiyah 1 Gamping Tahun Ajaran 2015/2016 Berdasarkan Gaya Kognitif Reflektif-Impulsif', pp. 5259, 2016.

[16] R. Yuliardi, P. Studi, and P. Matematika, 'Mathematics Learning Assisted by GeoGebra Software to Improve SMK Student's Spatial Ability and Mathematical Communication', Unnes J. Math. Educ., vol. 6, no. 1, pp. 121-127, 2017.

[17] W. Murtafi'ah and T. Masfingatin, 'Proses Berpikir Mahasiswa dengan Kemampuan Spatial Intellegent Tinggi dalam Memecahkan Masalah Geometri', J. Ilm. Pendidik. Mat., vol. 6, no. 1, pp. 133-148, 2015.

[18] T. K. Wahono, 'Kecerdasan Visual-Spasial Siswa Smp Dalam Menyelesaikan Soal Geometri Ruang Ditinjau Dari Perbedaan Kemampuan Matematika', Mathedunesa, vol. 3, no. 1, 2014. 